\title{
Almost Halfway There: An Analysis of the Open Access Behaviors of Academic Librarians
}

\author{
Holly Mercer
}

\begin{abstract}
Academic librarians are increasingly expected to advocate for scholarly communications reforms such as open access to scholarly publications, yet librarians do not always practice what they preach. Previous research examined librarian attitudes toward open access, whereas this article presents results of a study of open access publishing and self-archiving behaviors of academic librarians. Following an analysis of open access to library and information science literature in 2008, several strategies to encourage academic librarians to continue to embrace open access behaviors are discussed.
\end{abstract}

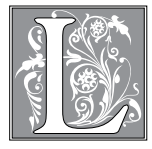

ibraries are hyperaware of the economic issues besetting the scholarly communication system; as the costs to purchase or license scholarly publications rise, libraries explore ways to manage those costs. Some academic and research libraries have responded by expanding their roles as curators of the scholarly record. Research libraries have adopted new roles in the production, dissemination, and preservation of the scholarly record, ${ }^{1}$ and academic librarians have assumed new responsibilities. Bibliographers and reference librarians have become liaisons who provide expanded services to academic departments. Liaison-librarians often are responsible for discussing scholarly communications topics, such as the rising cost of scholarly journal subscriptions and open access (OA) alternatives, and they are expected to advise authors to retain enough rights to their published work to use in the classroom, to share with colleagues, and to deposit in an institutional or subject repository.

With the expanded roles of libraries as publisher and increased expectations for subject librarians, one could assume academic librarians are well versed in scholarly communications topics, well prepared to share this knowledge with the rest of the academic community. A 2009 study by Palmer et al. concluded librarians are generally quite supportive of scholarly communications programs including opening access to scholarship, but are nonetheless ambivalent or unsure how to discuss these topics with faculty at their institutions. ${ }^{2}$

Academic librarians have responsibility for maintaining awareness and promoting services such as institutional repositories (IRs), as well as alternative publication venues such as open access journals, but do their behaviors reflect 
a commitment to open access because of their increased exposure to scholarly communication issues? Previous research examined librarian attitudes toward open access, whereas this article presents results of a study of open access publishing and self-archiving behaviors of academic librarians.

\section{Literature Review}

Previous studies suggest reasons why authors, regardless of discipline, may be hesitant to adopt new behaviors and methods of dissemination, including open access publication. Authors may misperceive the benefits and risks of open access, whether accomplished through publication in open access journals or deposit in institutional or subject repositories. In addition, respondents to one survey did not realize the advantages of disseminating their work via repositories in lieu of posting on their personal Web sites. $^{3}$

IRs are one route authors can take to open access for their works, but uptake has been slow. Reasons given for faculty resistance toward the IR at the University of Oregon are similar to those reported by Swan, including uncertainty about sustainability of digital technologies and long-term access, ignorance of copyright law, fear of weakening relationships with publishers, and concerns about disrupting the peer review process. ${ }^{4}$ IRs have a low barrier to entry on campuses that support a repository. This is especially true for academic librarians, since libraries have initiated and support many operating IRs. Yet, according to Salo, "Repository software serves observed and stated faculty needs surrounding content creation and dissemination hardly at all [sic]. ${ }^{5}$ The University of Rochester library investigated the discrepancy between the stated benefits of institutional repositories and the desires of faculty and found that most want to work with colleagues, as well as organize and manage their research and writing. ${ }^{6}$ IRs only minimally cater to these goals. Burris argues that a certification process, whereby items are evaluated for quality, would help add credibility to IRs because it would support faculty goals. For published articles, however, the certification process is associated with the journal rather than the IR. Availability of download and usage statistics for items in repositories is extremely important, yet not standard, and a lack of measures of impact may be a disincentive to participate. ${ }^{7}$

Björk et al. conducted a study in which they sought open access versions of a sample of scientific journal articles published in 2008. They found that 20.4 percent of articles in their sample were available OA, either on the publishers' Web sites, or from another Web site or repository. Open access to articles in the sample varied by discipline; the authors attributed these differences to factors such as the availability of subject repositories or preprint servers in some disciplines, as well as an uneven availability of funds to pay for author fees or publication charges. ${ }^{8}$

Carter, Snyder, and Imre conducted a survey of library faculty at ten institutions to learn about librarian publishing activities, library faculty attitudes toward the production of scholarship, and the policies in place at those ten academic research libraries. The authors note that "librarians as authors should be the most prominent supporters of open access, and that, as scholars, they would practice self-archiving." ${ }^{\prime 9}$ Yet 50 percent of library faculty who responded to the survey indicated that their only concern with the publishing process was getting their articles published. Other reasons given for selecting a specific journal were journal reputation, the (presumably short) review period, or philosophical or moral reasons. Only 12 percent of respondents had made their articles available in an open access repository or personal Web site. This is a lower percentage than the 49 percent the Swan and Brown study reported for all survey participants, and lower than the number reported for library and 
information science faculty specifically (between $10 \%$ and $31 \%$, depending on self-archiving method employed). ${ }^{10}$

Carter et al. conclude, "The results of the questions related to the copyright and intellectual property rights of publishers, including self-archiving, compared with national and international data for faculty members in all disciplines showed that the library faculty members are not practicing what they generally advocate."11 Academic librarians believe the profession should advocate for OA, but few said they were supporting OA by taking action individually, such as self-archiving or amending publication agreements. ${ }^{12}$

Librarians who engaged in OA behaviors had more positive attitudes toward $\mathrm{OA}$, and those with some responsibility for managing open access projects had higher opinion scores than their colleagues without those responsibilities. ${ }^{13}$ Institutions with active scholarly communication programs and open access campaigns employed librarians with more favorable attitudes toward open access than other institutions. ${ }^{14}$

Salo observed that librarians do not use IRs to distribute their work and that subject librarians are not encouraging faculty to do so, either. "Poor repository uptake among academic librarians invites faculty to charge their libraries with hypocrisy, particularly at institutions where librarians are tenured: if librarians themselves do not adopt the very practice they are so busily evangelizing to faculty can it really be any good?"15

The Palmer et al. study showed "the discrepancy between librarian support of open access concepts and actions taken that reflect this stated support."16 However, 89 percent of respondents to the Carter et al. survey said they would comply with an administrative mandate to self-archive their publications, compared to 81 percent of the Swan and Brown study of researchers across disciplines and 94 percent of the library and information science respondents. ${ }^{17}$ Academic librarians might be willing to adopt OA behaviors if presented with a compelling reason for doing so, such as a departmental or institutional mandate to self-archive.

Researchers have studied differences between the scholarly publishing practices of practitioner librarians and researchers in library and information science. Schlögl and Stock found a low degree of information exchange between academic and practitioner journals in library science, ${ }^{18}$ which could explain differences in rates of open access adoption between practitioners (academic librarians) and researchers (teaching faculty).

\section{Methodology}

Surveys can show the attitudes toward $\mathrm{OA}$ and scholarly communications reform, but they do not document author behaviors. Since academic librarians are long-time stakeholders in scholarly communications reforms, one might assume they will make their own publications available open access at higher rates than academic colleagues in other disciplines. In this article, academic librarians' 2008 publications are analyzed to better understand whether they employ open access methods to make their research available and to offer possible reasons for academic author-librarian behaviors and motivations, with an eye to increasing awareness of and activism in scholarly communication among this group. Based on an analysis of LIS English language peer-reviewed journal articles published in 2008, academic librarians engage in OA behaviors at slightly higher rates than peer authors, but not as often as is allowed under current publisher policies.

LISA, Library Information Science Abstracts, was selected as the data source for the study because it indexes peerreviewed library and information science journals, including research and practicebased titles. Borrego et al. found that LISA indexed 32 percent of library and information science journals listed in the Directory of Open Access Journals (DOAJ) in $2007,,^{19}$ so the data source includes open 


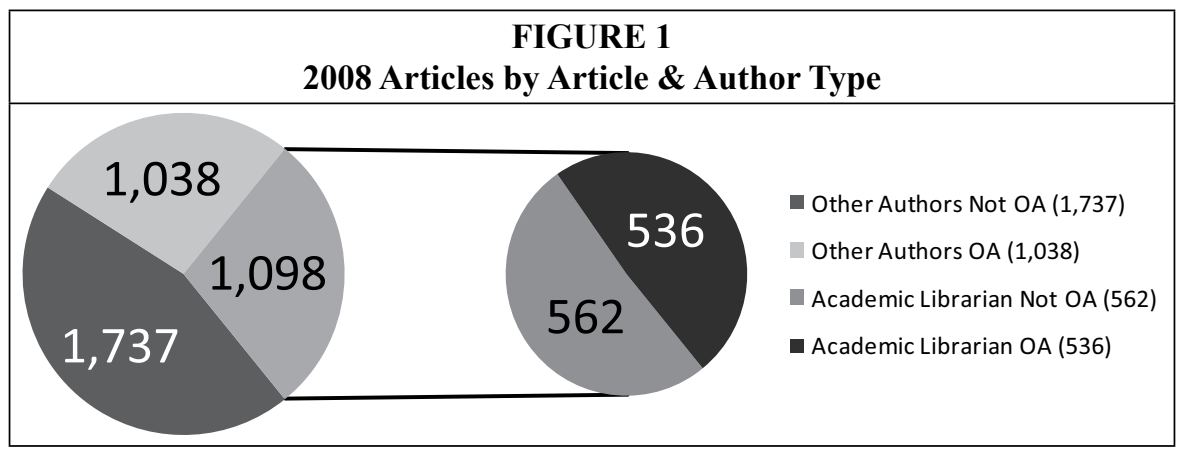

access and subscription titles. The dataset only includes articles published in English, but it is otherwise diverse and includes journals published in countries where English is not the primary language (such as Webology, ${ }^{20}$ published by the University of Tehran) and journals whose scope is a particular geographic region (African Journal of Library, Archives, $\mathcal{E}$ Information Science ${ }^{21}$ ) or culture or ethnicity (Chinese Librarianship: An International Electronic Journal ${ }^{22}$ ). Articles published in open access and subscription-based journals were included. A search of LISA for English-language peer-reviewed articles published in 2008 initially identified 4,641 articles. The citations were imported into a RefWorks library and de-duplicated.
The author removed all articles without at least one author identified, resulting in 3,873 articles. The citations were analyzed to determine whether the first author or corresponding author was an academic librarian. Only primary or corresponding authors' affiliations were examined. Then the citations were grouped into two categories: articles authored by academic librarians and articles authored by anyone else. Librarians at public, national, or state libraries, or research libraries and archives not affiliated with a college or university, are included in the other category. Vendors, independent researchers, and teaching faculty including library and information school faculty were also categorized as other. Of the 3,873 peer-

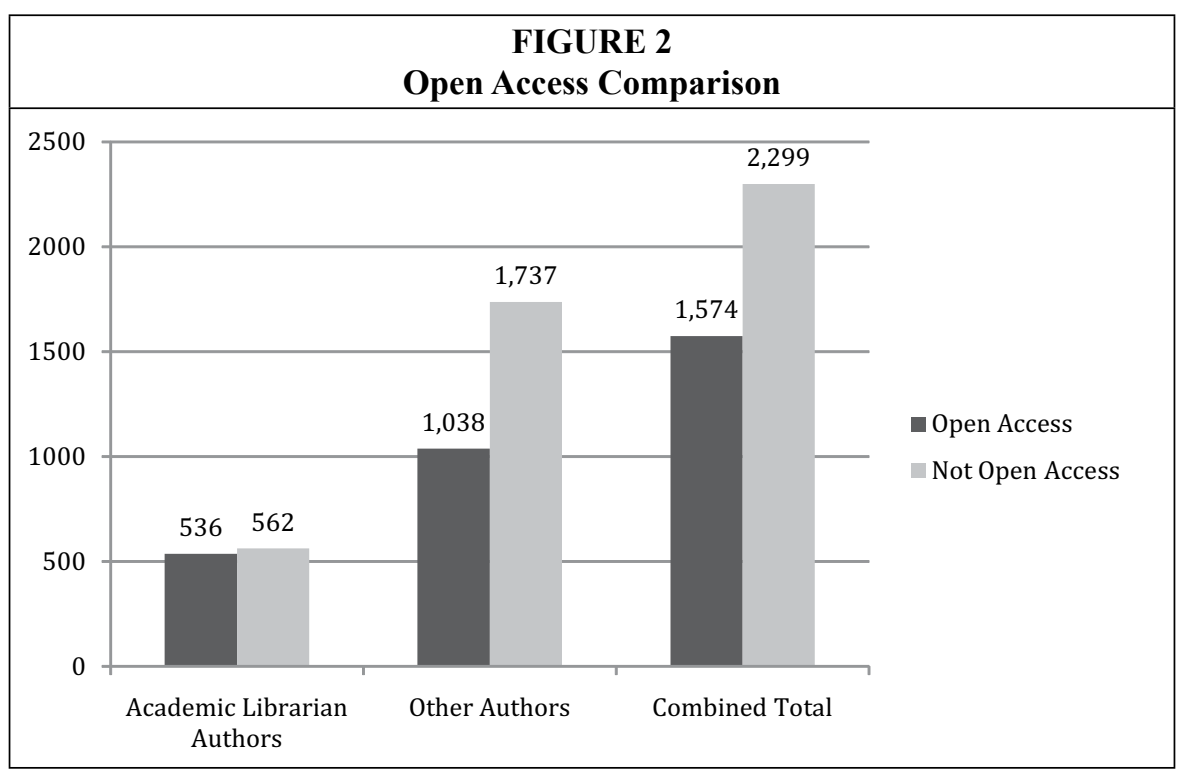




\begin{tabular}{|l|c|c|c|}
\hline \multicolumn{4}{|c|}{ TABLE 1 } \\
\hline & $\begin{array}{c}\text { Open Access at time } \\
\text { of study }\end{array}$ & $\begin{array}{c}\text { Eligible for Open } \\
\text { Access at time of } \\
\text { publication }\end{array}$ & $\begin{array}{c}\text { Eligible for Open } \\
\text { Access by January } \\
2011\end{array}$ \\
\hline Academic Librarian & $536(48.81 \%)$ & $642(58.47 \%)$ & $1,037(94.44 \%)$ \\
\hline Others & $1,038(37 \%)$ & $2,023(73 \%)$ & $2,473(89 \%)$ \\
\hline All Authors & $1,574(40.64 \%)$ & $2,665(68.81 \%)$ & $3,510(90.63 \%)$ \\
\hline
\end{tabular}

reviewed articles that met these criteria, librarians working in college or university libraries or archives authored 1,098, or 28 percent. Other authors produced the remaining 2,775 articles in the dataset (see figure 1).

\section{Results}

Several findings were particularly noteworthy. Almost 49 percent of academic librarian authors' articles were available open access (see figure 1). Granted, this percentage includes articles that are open access by methods other than self-archiving, but it is higher than the self-archiving rates found by previous studies. ${ }^{23}$ Although academic librarians authored fewer total articles, their OA choices compare favorably to the other authors in LIS journals (see figure 2). Still, fewer articles were available open access than were eligible for self-archiving in some type of repository based on publisher policies for both author types (see table 1).

The analysis of 2008 citations from LISA indicates a low degree of information exchange between academic librarians and other authors in library and information science journals. Sixty-three publishers published 180 journal titles. Eighty-five journals included no articles authored by academic librarians; only one journal (Journal of Access Services) had articles written exclusively by academic librarians (see table 2).

Open access or not-for-profit publishers such as university presses and professional associations published fewer total articles than commercial publishers. Imprints were included with the larger publishing company; for example, Routledge titles were included as Taylor and Francis publications. As one can see in table 3, twenty commercial publishers produced $126(70 \%)$ of the titles in the dataset; forty-three nonprofit publishers publish the remaining fifty-four journal titles. ${ }^{24}$ There were 1,098 English-language peerreviewed articles written by academic librarians and published by 42 publishers in 95 journals in 2008.

Twenty-three open access journals contained 463 articles, accounting for 12 percent of all articles and 14 percent of all those authored by academic librarians from the dataset. Just over 40 percent $(1,574)$ of articles in the dataset had some version (preprint, author final draft, or published version) available open access by any method-open access journal, on the publisher or journal Web site, in an institutional or subject repository, or on a personal or other Web site. However, more could have been available open access than were, based on publisher policies toward self-archiving (see table 1 ) as recorded in the SHERPA RoMEO

TABLE 2
\begin{tabular}{|l|c|c|c|c|c|}
\hline Most Journals in the Dataset Included More Articles Written by Other \\
Authors Than by Academic Librarians \\
\hline \% Academic Librarian Authored Articles & $\mathbf{0 \%}$ & $\leq \mathbf{5 0 \%}$ & $\mathbf{> 5 0 \%}$ & $\mathbf{1 0 0 \%}$ \\
\hline Number of Journals & 85 & 55 & 39 & 1 \\
\hline
\end{tabular}


TABLE 3

Breakdown of Total Articles, Journal Titles, and Publishers by Journal Type

\begin{tabular}{|l|c|c|c|c|c|c|}
\hline & \multicolumn{3}{|c|}{ All Authors } & \multicolumn{3}{c|}{ Academic Librarian Authors } \\
\hline & Articles & Journals & Publishers & Articles & Journals & Publishers \\
\hline $\begin{array}{l}\text { Commercial Publisher } \\
\text {-Subscription }\end{array}$ & 2,863 & 126 & 20 & 776 & 59 & 13 \\
\hline Commercial OA & 0 & 0 & 0 & 0 & 0 & 0 \\
\hline $\begin{array}{l}\text { Nonprofit } \\
\text {-Subscription }\end{array}$ & 547 & 31 & 23 & 165 & 20 & 15 \\
\hline Nonprofit OA & 463 & 23 & 22 & 157 & 16 & 16 \\
\hline Total & 3,873 & 180 & 63 & 1,098 & 95 & 42 \\
\hline
\end{tabular}

Note: Publisher counts do not add up to 63 because two publishers produce both open access and subscription journals

database..$^{25}$ Sixty-eight percent, or 2,665, could have been open access based on publisher policies on self-archiving and copyright. Taylor and Francis or its imprints published $764(19.7 \%)$ of the total articles included in the dataset. This publisher also produced a large number of academic librarian-authored articles; Taylor and Francis published 407 (37\%) of these articles in one quarter $(\mathrm{N}=24)$ of the journals in 2008. Taylor and Francis journals are subject to a twelve- or eighteen-month embargo.

Wholly 94 percent $(1,037)$ of the academic librarian-authored articles from the dataset were eligible for open access by any method by January 2011 . Many commercial publishers allow self-archiving of some version of journal articles, and academic librarians are electing to self-archive at rates higher than other academics and practitioners who are publishing in the same journals (see table 1). Just less than half $(48.81 \%)$ of academic librarian-authored articles were available open access at the time of the study. This percentage is higher than other authors' articles (40.64\%). While many more academic librarians could opt for open access to their work, these numbers are promising.

\section{Discussion}

Björk et al. found that 20.4 percent of sampled scientific journal articles were open access. ${ }^{26}$ That study differs from the one presented here in terms of how data was gathered, but it is nonetheless interesting to note that the rates of open access among academic librarians compared very favorably to those of authors in scientific journals.

Librarians' position descriptions and professional associations' advocacy efforts may minimally affect OA behavior. A recent Association of Research Libraries (ARL) report on the changing roles of library subject liaisons described how the University of Minnesota identified ten areas of responsibility for subject librarians in its position descriptions, including scholarly communication. For example, an activity listed under the scholarly communication area is "Advocate for sustainable models of scholarly communication." ${ }^{27}$ Programs such as the Association of College and Research Libraries (ACRL) / ARL Scholarly Communications Institutes and the Scholarly Communications 101 Road Show are designed to equip academic librarians with the knowledge and skills to advocate for changes in the scholarly communications system, and librarians from a range of academic libraries have attended these practical, action-oriented workshops. Yet even at the University of Minnesota, where scholarly communication responsibilities have been "mainstreamed" into the expectations of subject librarians, there 
is a "steep learning curve" and liaison librarians are reluctant to be advocates for change. ${ }^{28}$

Many library professional associations, such as ARL, ${ }^{29}$ ACRL, Medical Library Association (MLA) ${ }^{30}$ and the Association of Academic Health Science Librarians (AAHSL), ${ }^{31}$ have strategic initiatives or Web sites designed to promote systematic changes in scholarly publishing that are more favorable to libraries and to readers. Academic library conferences often feature panels and papers on scholarly communications-related topics, where academic librarians are exposed to positive messages about open access and selfarchiving.

The American Library Association (ALA) not only advocates for scholarly communication reform, but it also has generous policies concerning author rights. The "Author Copyright Agreements for ALA Division Journals and Newsletters" allows an author to select either a license agreement, whereby the author retains copyright, or an assignment agreement, where copyright is transferred to the ALA. ${ }^{32}$

The ALA and ACRL have embraced $\mathrm{OA}$ and author retention of rights, and the number of open access journals in library and information science is increasing. Consequently, academic librarians are opting to publish their articles in OA journals. There were 75 open access scholarly journals published in the library and information science field in 2007 and at least 48 open access digital repositories with library and information science content. ${ }^{33}$ The number is rising; the Directory of Open Access Journals listed 103 active and ceased library and information science journals as of May 2010, a 37 percent increase from the 2007 count.

\section{Analysis/Recommendations}

All academic librarian authors were considered as a homogenous group for this study, but there is great diversity among the group. Differing job responsibilities, work environments, terms of appoint- ment, and professional status make it difficult to determine motivations for publishing and choosing open access methods of distribution. Academic librarians provide services in support of teaching and research faculty and may also engage in research and scholarly activities. Whether as a requirement to meet the expectations for promotion, tenure, or continuous appointment or to advance the profession or field, academic librarians are also authors of peer-reviewed scholarship. Their motivations for publishing or selecting open access methods will differ because their professional expectations vary.

Jenkins et al. identified disciplinespecific factors that create reluctance to participate in an IR. Most do not apply to the field of librarianship, such as "failure among professional associations to prioritize changes in scholarly publishing." ${ }^{34}$ Library professional associations have been clear in their support for and prioritization of scholarly communication issues. However, one discipline-specific factor is applicable to library and information science, "disciplines where only a few publishers control the journals." ${ }^{35}$ Taylor and Francis, for example, publishes thirty-nine of 180 journals included in the study. Authors might be reluctant to deposit their articles in institutional repositories or to challenge Taylor and Francis' embargo period on self-archiving if those actions might affect publication. Jenkins et al. state that academia, as a whole, is risk-averse. ${ }^{36}$ Academic librarians, as members of the academy, are presumably no different from their colleagues in higher education. Or, librarians may be risk takers in their professional roles, where they are actively encouraging changes in the system of scholarly communication and adoption of new technologies but are risk-averse as faculty in their roles as researchers and authors.

Combined with recent studies of librarian attitudes toward publication and open access, this study brings into sharp focus the challenges and opportunities of increasing the prevalence of open access to 
library and information science literature. There are strategies to increase uptake of open access within the academic librarian community. Salo lists several ideas to improve the situation, including better education, top-down support of $\mathrm{OA}$, and expanded digital library services. ${ }^{37}$ These ideas and others are discussed in the following paragraphs.

\section{Refine Graduate Programs in Library and Information Science}

Library and information science programs can incorporate repository and open access principles into the curriculum, along with an introduction to copyright, fair use, and especially author rights. Repositories have been available for long enough to be included in courses, and a better introduction to scholarly communication would help prepare future academic librarians for roles as liaisons and open access advocates. Academic librarians need to know how to read and interpret publication contracts. Graduate programs in library and information science can also place greater emphasis on the role of librarians as researchers and authors.

\section{Implement Scholarly Communications Continuing Education Programs in All Types of Academic Libraries}

Academic libraries can follow the University of Minnesota's example and formalize the expectations for subject librarians to promote open access behaviors among the faculty. ${ }^{38}$ Librarians who are actively engaged in scholarly communications initiatives are more likely to adopt open access behaviors.

Scholarly communication officers and repository managers can continue to work with liaison librarians to allay concerns about open access publishing. Once authors understand what publishers allow by default, such as posting the author final draft of an article in an IR, authors' concerns about strained relationships with publishers might be reduced or eliminated. Academic librarian-authors may need assistance in understanding publication contracts and negotiating the right to deposit in an OA repository if the publisher does not allow this by default. It is also important to be understanding of the frustrations and challenges subject librarians face in their liaison roles; they are expected to learn and apply new technologies at the same time they are developing deeper understanding of their subject disciplines.

Not all academic libraries have scholarly communication officers or repository managers, but academic librarian-authors work in all types and sizes of academic libraries. Continuing education and exposure to the issues are critical to encourage academic librarians to model the behaviors they espouse. Arming subject librarians in particular with the knowledge and confidence will enhance both their liaison work with teaching faculty and in their roles as authors and contributors to a healthy scholarly communication system.

\section{Offer Repository-related Suite of Services for Scholars}

Repositories should be one component in a suite of library services in support of research dissemination, such as scanning, metadata record creation and enhancement, and rights management. ${ }^{39}$ These services should be available to all faculty and staff responsible for research and publication. Librarians would have opportunities to use these services and, in doing so, would become better equipped to promote them to those outside the library organization. Protocols such as Simple Web-service Offering Repository Deposit (SWORD) ${ }^{40}$ may benefit IRs by allowing faculty or designees to submit an article once for deposit in multiple repositories.

Repository managers can explain what certification measures, if any, exist for their institutions' repositories. Standardizing how usage statistics are collected and measured in repositories would provide the "certification" for which Burris advocates ${ }^{41}$ by providing one measure of 
impact, though not of quality. Certainly, it would assist authors and readers comparing impact of different works in different repositories if the measures were handled the same way.

Authors who receive usage reports for deposited works are likely to have a better understanding of the impact of open access. Open access publications are readily available so they are easy for promotion and tenure committees and external evaluators to review. If repository statistics are enabled, repositories can help make the case for scholarly impact. Services such as CiteSeerX, a digital library and search engine for computer and information science that uses automated citation linking, includes articles from open access repositories. ${ }^{42}$ Open access journals are indexed in databases and scholarly indexes so they have at least as great a chance of being cited as subscription journals in the discipline. Peers can better locate and read works, and it is easier to see what others are doing, establish networks, and identify future collaborators.

\section{Become Activists for Changes in the Scholarly Publishing System}

Librarians and author-librarians can pressure publishers to allow self-archiving of the author's final draft immediately upon publication. Rather than relying on authors to negotiate changes in publication contracts on a per-article basis, authors and institutions should work together to negotiate publication agreements (such as the use of author addenda) at the journal or publisher level. Also, librarians can propose innovative new models for achieving open access to LIS research, such as the high energy physics community did with SCOAP ${ }^{3}$ (Sponsoring Consortium for Open Access Publishing in Particle Physics). ${ }^{43}$

There is a void in library literature in terms of scholarly communications issues. While there are peer-reviewed journals that publish research on digital libraries and scholarly publishing, academic librarians are often not the primary or target audience. Establishment of an open access journal devoted to scholarly communication advocacy and academic libraries would fill a void and would provide opportunities for learning from colleagues and for sharing successes.

\section{Support for Open Access by Administrators and Tenure Committees}

Academic librarians are not likely to adopt activist behaviors without support from library and college or university administrators. For academic librarians with faculty appointments or who otherwise have an expectation for research and publication, promotion and tenure committees and administrators can establish expectations for self-archiving publications. Rather than being seen as an activity that adds little value to the scholarly communication process (or tenure prospects), tenure and promotion committees can encourage authors to deposit allowable copies into an institutional or subject repository. Freely available research can be referred to by candidates in their dossiers, and referenced easily by committees and external evaluators. As is becoming the norm in the United Kingdom and Australia, ${ }^{44}$ promotion and tenure committees should not reflexively penalize candidates for selecting open access journal venues, but rather focus on the quality and impact of the articles themselves.

Library administrators should value repositories and open access principles-and make use of them. Library deans and directors should support author-librarians who might decline to sign copyright transfer agreements that prohibit self-archiving without delays or embargoes. Library deans and directors can model open access behaviors by selfarchiving their own works in subject or institutional repositories. Tacit support for open access is admirable, but active participation demonstrates institutional commitment.

Finally, influential librarians, early adopters, and library administrations 
can advocate for adoption of practices and policies that encourage open access to research in the discipline. A policy on open access to published scholarship is the easiest route to widespread adoption of open access. Since 2008, several U.S. colleges and universities have announced open access policies or mandates, including departmental mandates within libraries. Whether these policies have a positive effect on self-archiving remains to be seen. This study did not address the open access behaviors of librarians whose institutions or libraries adopted open access policies or mandates, but it would be interesting to investigate whether open access mandates affect attitudes and behaviors of librarians at those institutions.

\section{Conclusion}

Academic librarians face many of the same challenges, motivations, and pressures as their teaching and research faculty colleagues. Those in tenure-track positions may not wish to disrupt rela- tionships with publishers, since publication is a necessary step in most tenure and promotion processes. They might feel pressure to publish to meet tenure and promotion expectations, and they may be unwilling to take action that may hurt, or at the least not help, chances for academic or professional advancement. Incentives and benefits of opting for $\mathrm{OA}$ (irrespective of method) must align with the needs and objectives of all researchers, including academic librarians.

Academic librarians can more effectively model the behaviors they are often tasked to encourage in others. A variety of strategies should be implemented or continued with additional resources and effort. Only over time will it be possible to learn whether these efforts are worthwhile, but, given the generally positive attitudes academic librarians have toward open access, there is certainly hope. After all, almost 49 percent of academic librarian authors' articles were open access in 2008, and that is almost halfway there.

\section{Notes}

1. Karla L. Hahn, Research Library Publishing Services: New Options for University Publishing (Washington, D.C.: Association of Research Libraries, 2008). Available online at www.arl.org/ bm doc/research-library-publishing-services.pdf. [Accessed 06 March 2010].

2. Kristi L. Palmer, Emily Dill, and Charlene Christie, "Where There's a Will There's a Way? Survey of Academic Librarian Attitudes about Open Access," College \& Research Libraries 70, no. 4 (July 2009): 315-35.

3. Alma Swan, The "Big Picture" and Researchers' Top Concerns about the Scholarly Communication Process: A Report for the JISC Scholarly Communications Group. Cornwall, UK: Scholarly Communication Group, Joint Information Systems Committee, 2008. Available online at http:// eprints.ecs.soton.ac.uk/15450/. [Accessed 9 June 2010].

4. Barbara Jenkins, Elizabeth Breakstone, and Carol Hixson, "Content in, Content Out: The Dual Roles of the Reference Librarian in Institutional Repositories," Reference Services Review 33, no. 3 (2005): 312-24.

5. Dorothea Salo, "Innkeeper at the Roach Motel," Library Trends 57, no. 2 (Fall 2008): 98-123.

6. Nancy Fried Foster and Susan Gibbons, "Understanding Faculty to Improve Content Recruitment for Institutional Repositories," D-Lib Magazine 11, no. 1 (Jan. 2005). Available online at www.dlib.org/dlib/january05/foster/01foster.html. [Accessed 15 June 2010].

7. Brigitte Burris, "Institutional Repositories and Faculty Participation: Encouraging Deposits by Advancing Personal Goals," Public Services Quarterly 5, no. 1 (2009): 69-79.

8. Bo-Christer Björk, Patrik Welling, Mikael Laakso, Peter Majlender, Turid Hedlund, Guðni Guðnason, "Open Access to the Scientific Journal Literature: Situation 2009," PLoS ONE 5, no. 6 (2010): e11273. doi:10.1371/journal.pone.0011273. [Accessed 31 August 2010].

9. Howard Carter, Carolyn A. Snyder, and Andrea Imre, "Library Faculty Publishing and Intellectual Property Issues: A Survey of Attitudes and Awareness," portal: Libraries and the Academy 7, no. 1 (2007): 65-79.

10. Alma Swan and Sheridan Brown, Open Access Self-Archiving: An Author Study (Cornwall, U.K.: Key Perspectives, 2005), 27-30. Available online at www.jisc.ac.uk/media/documents/themes/ infoenvironment/oaselfarchivingauthorstudy.pdf. [Accessed 16 March 2010]. 


\section{An Analysis of the Open Access Behaviors of Academic Librarians 453}

11. Carter, Snyder, and Imre, "Library Faculty Publishing," 77.

12. Ibid, 73; Palmer, Dill, and Christie, "Where There's a Will," 320.

13. Ibid, 320.

14. Ibid, 327.

15. Salo, "Innkeeper at the Roach Motel," 105.

16. Palmer, Dill, and Christie, "Where There's a Will," 327.

17. Carter, Snyder, and Imre, "Library Faculty Publishing," 74; Swan and Brown, Open Access Self-Archiving, 63-64.

18. Christian Schlögl and Wolfgang G. Stock, "Practitioners and Academics as Authors and Readers: The Case of LIS Journals" Journal of Documentation 64, no. 5 (2008): 643-66.

19. Angel Borrego, Candela Olle, and Marta Somoza, "An Overview of LIS Open Access Literature," in Academic Librarianship in the 21st Century, eds. Claudia M. Garcia and Teresa A. Flores (New York: Nova Science Publishers, 2009), 6.

20. Webology. Available online at http://webology.ir/. [Accessed 15 June 2010].

21. African Journal of Library, Archives, $\mathcal{E}$ Information Science. Available online at http://ajol.info/ index.php/ajlais. [Accessed 15 June 2010].

22. Chinese Librarianship: An International Electronic Journal. Available online at www.whiteclouds.com/iclc/cliej/. [Accessed 15 June 2010].

23. Swan and Brown, Open Access Self-Archiving, 60; Carter, Snyder, and Imre, "Library Faculty Publishing," 73.

24. Archlib Information Services and the American Library Association both produced at least one subscription and one open access journal, and therefore the total count of publishers does not appear correct.

25. "SHERPA RoMEO Publisher Copyright Policies \& Self-Archiving" (Nottingham, UK: University of Nottingham, 2006). Available online at www.sherpa.ac.uk/romeo/. [Accessed 10 October 2009].

26. Björk et al., "Open Access to the Scientific Journal Literature."

27. Karen Williams, "A Framework for Articulating New Library Roles," Research Library Issues no. 265 (August 2009): 3-8. Available online at www.arl.org/bm doc/rli-265-williams.pdf. [Accessed 10 October 2009].

28. Kara J. Malenfant, "Leading Change in the System of Scholarly Communication: A Case Study of Engaging Liaison Librarians for Outreach to Faculty," College \& Research Libraries 71, no. 1 (Jan. 2010): 63-76.

29. Association of Research Libraries, Reshaping Scholarly Communication (Chicago: Association of Research Libraries). Available online at www.arl.org/sc/index.shtml. [Accessed 28 May 2010].

30. Medical Library Association, "Resources: MLA Scholarly Communications Issues." Available online at www.mlanet.org/resources/publish/index.html. [Accessed 14 June 2010].

31. Association of Academic Health Sciences Libraries, "Scholarly Communication Toolkit: Promotion of Open Access by Libraries." Available online at www.aahsl.org/mc/page/toolkit05. [Accessed 14 June 2010].

32. American Library Association, Author Copyright Agreements for ALA Division Journals and Newsletters (Chicago: American Library Association, 2009).

33. Borrego, Olle, and Somoza, "An Overview of LIS Open Access," 92.

34. Jenkins, Breakstone, and Hixson, "Content in, Content Out," 316.

35. Ibid, 316.

36. Ibid, 315.

37. Salo, "Innkeeper at the Roach Motel," 118.

38. Williams, "A Framework for Articulating New Library Roles," 4.

39. Salo, "Innkeeper at the Roach Motel," 118.

40. "Welcome to SWORD APP." Available online at www.swordapp.org/. [Accessed 1 July 2010].

41. Burris, "Institutional Repositories," 72.

42. "About CiteSeerX," CiteSeer ${ }^{\mathrm{X}}$ beta Scientific Literature Digital Library and Search Engine. Available online at http://citeseerx.ist.psu.edu/. [Accessed 1 July 2010].

43. SCOAP' ${ }^{3}$ : Sponsoring Consortium for Open Access Publishing in Particle Physics. Available online at http://scoap3.org/. [Accessed 1 July 2010].

44. "Research Excellence Framework," Higher Education Funding Council for England, available online at www.hefce.ac.uk/research/ref/ [accessed 1 July 2010]; "The Excellence in Research for Australia (ERA) Initiative," Australian Research Council, available online at www.arc.gov. au/era/default.htm [accessed 1 July 2010]. 